\title{
The Activity of Family Businesses and the Phenomenon of Underpricing of Their Shares in IPOs in Poland in the Years 2013-2015
}

\author{
Pawet Perz*
}

\begin{abstract}
A lack of sufficient capital is sometimes one of the barriers for the development of family firms. In a situation when company owners do not have the possibility to recapitalize the company or to increase the scale of the use of borrowed capital, an issue of shares directed to external entities may become an important source of funding. The article analyzes the activity of family firms in the process of raising capital through the issue of shares on the public market of securities, namely the stock exchange, and in the alternative trading system - the NewConnect market. The analysis was conducted based on data from 2013-2015. In that period, the share issues of family firms accounted for $30 \%$ of all IPOs on the Warsaw Stock Exchange and $43 \%$ on the NewConnect market. The article also examines the phenomenon of stock underpricing in the initial public offering. The scales of underpricing in family firms and other companies are compared.
\end{abstract}

Keywords: family firms, IPO, NewConnect, Warsaw Stock Exchange.

Submitted: 22.08.2016 | Accepted: 22.10.2016.

\section{Aktywność firm rodzinnych i zjawisko niedowartościowania ich akcji w pierwszych ofertach sprzedaży akcji (IPO) w Polsce w latach 2013-2015}

Brak wystarczających zasobów kapitałów bywa jedna z barier rozwoju firm rodzinnych. $W$ sytuacji, kiedy wtaściciele firmy nie mają możliwości dokapitalizowania przedsiębiorstwa ani nie ma możliwości zwiększania skali wykorzystania kapitału obcego, istotnym źródtem finansowania może stać się emisja akcji skierowana do zewnętrznych podmiotów. W artykule dokonano analizy aktywności firm rodzinnych $w$ procesie pozyskiwania kapitału poprzez emisję akcji na publicznym rynku papierów wartościowych - Giełdzie Papierów Wartościowych oraz w alternatywnym systemie obrotu - na rynku NewConnect. Analize przeprowadzono na podstawie danych z lat 2013-2015. W badanym okresie emisje akcji w firmach rodzinnych stanowity odpowiednio 30\% wszystkich debiutów na GPW w Warszawie $i 43 \%$ na rynku NewConnect. $W$ artykule zbadano również znane $w$ literaturze zjawisko niedowartościowania cen akcji w pierwszych ofertach sprzedaży akcji. Porównano skale niedowartościowania $w$ firmach rodzinnych i pozostalych przedsiębiorstwach.

Paweł Perz, PhD, Eng. - Department of Finance, Banking and Accounting; Faculty of Management, Rzeszow University of Technology.

Mailing address: Rzeszow University of Technology, al. Powstańców Warszawy 10, 35-959 Rzeszów; e-mail: pperz@prz.edu.pl. 
Słowa kluczowe: firmy rodzinne, IPO, NewConnect, GPW w Warszawie.

Nadesłany: 22.08.2016 | Zaakceptowany do druku: 22.10.2016

JEL: G3

\section{Introduction}

Due to a number of specific features and an important role in the economy, family firms are becoming of increasing interest among researchers (Craig and Salvato, 2012; Melin, Nordqvist and Sharma, 2013). According to the data from the European Commission, family firms account for about $60 \%$ of all companies in the economy (European Commission, 2009). They are most often formed as small businesses and if they achieve market success, they are transformed into growing companies.

In order to implement development plans, companies must have the necessary capital, which often requires reaching for external capital. In the literature on family businesses in developed markets, we can find estimates related to the share of these companies in the total number of companies listed on stock exchanges. For the US market, R. Anderson and D. Reeb estimated that $1 / 3$ of companies included in the S\&P 500 index are family companies (Anderson and Reeb, 2003). Estimates for the total number of the largest US companies point to an even larger percentage of this type of enterprises, suggesting that $48 \%$ of 2000 largest companies in the USA are companies controlled by families (Anderson, 2006). According to the best knowledge of the author, there is a lack of such estimates for companies listed on the capital market in Poland, and therefore this issue seems to be interesting and worth exploring. The article attempts to achieve two goals. The first objective is to assess the presence of family businesses among companies conducting IPOs in the period 2013-2015 and to compare the activity of family businesses on the market of the Warsaw Stock Exchange and in the alternative trading system NewConnect. The second goal is to develop a comparative analysis of the degree of underpricing of family companies and other offerings in the first sale of shares. This goal stems from a desire to check whether this type of differentiation exists in the Polish market. Studies on other markets do not clearly answer this question. Some authors indicate that owners of family businesses decide on greater underpricing to protect socio-emotional wealth, that is the noneconomic utility that a family derives from its ownership position in a company (Leitterstorf and Rau, 2014). In other studies, there was no relationship between the ownership structure and the scale of share underpricing in the first sales offers (Hill, 2006). The analysis prepared in this article is to be a voice in the debate on this issue in the literature.

The analysis was conducted using data on the first tender sale of shares on the Warsaw Stock Exchange and on the alternative NewConnect market in 2013-2015. The analysis covered the data on 81 companies debuting on the Warsaw Stock Exchange and 83 companies from NewConnect. In order to classify the companies to a group of family businesses, the data from the prospectuses (in the case of the Stock Exchange) and information documents (the companies from NewConnect) were used.

My main findings can be summarized as follows. The percentage of family businesses making their debut on the Warsaw Stock Exchange in the period 2013-2015 amounted to $30 \%$ of all companies conducting IPOs; on the NewConnect market, the share of family businesses was slightly higher and reached $42 \%$ of all IPOs in that period. The owners of family businesses decided to sell a part of their shares in the IPO far less frequently than the shareholders of other companies. For the WSE, the share of the value of shares sold by existing owners was only $8 \%$, and on the NewConnect market $18 \%$.

Significant underpricing of shares sold in the IPO on NewConnect $(33.1 \%$ of all companies) was confirmed. For the Warsaw Stock Exchange, underpricing of shares in the period amounted to only $3.5 \%$ (for the 
total number of companies). There were no significant differences in the level of underpricing of the share price between family and non-family companies.

The article is organized as follows. Section 2 presents an overview of the relevant literature on raising capital by family firms and IPO underpricing. Section 3 provides information about the activity of companies on the IPO market in Poland in the years 2013-2015. In section 4, I have presented the empirical data about the activity of family firms on the IPO market in Poland in the years 2013-2015. Section 5 provides data about underpricing of family firms shares in IPOs in Poland in 2013-2015, and section 6 presents the conclusions.

\section{Literature Review}

The literature extensively describes phenomena related to Initial Public Offerings (IPOs). The considerations tend to focus on two groups of issues. The first group concerns: the price at which the shares are sold in the offer, the price of their stock exchange debut and behavior of share prices after the debut. The second group of issues includes an analysis of the motives that drive the company to sell its shares, and the consequences of the issue (Perz, 2003). Studies in many countries confirmed the phenomenon of the aboveaverage rate of return on the shares purchased in the offer and sold on the first day of IPO (Ritter and Welch, 2002; Loughran, Ritter and Rydqvist, 1994). This phenomenon was also confirmed for the Polish market (Jewartowski and Lizińska, 2012; Sieradzki, 2013; Gemzik-Salwach and Perz, 2013). A large difference between the IPO and the sales price of shares means that the company could sell itself for more, acquiring more resources; in the English literature, the money that could potentially be acquired (during the sales of shares at IPO prices) is referred to as "money left on the table". The scale of this phenomenon is revealed by the study for the US market in the years 1980-2001, where the value of these funds amounted to $\$ 106$ billion (Ritter and Welch, 2002). However, in some studies it was found that in family firms selling their shares the undervalued scale was greater than in other companies ( $\mathrm{Yu}$ and Zheng, 2012; Leitterstorf and Rau, 2014).
According to some studies, family firms utilize IPO underpricing in order to retain family control using underpricing to reduce outside blockholdings ( $\mathrm{Yu}$ and Zheng, 2012) or to help protect their reputation (Lovry and Shu, 2002). Some authors indicate that the owners of family businesses choose greater underpricing to protect "socioemotional wealth (SEW), i.e., the noneconomic utility a family derives from its ownership position in a firm" and argue that "the additional discount at which families are willing to sell shares at the IPO serves as a first proxy for the cost of SEW preservation" (Leitterstorf and Rau, 2014). However, research in this area does not produce conclusive results, as in other studies there was no relationship between the ownership structure and the scale of share underpricing in the first sales offers (Hill, 2006). In my opinion, most motifs to explain underpricing of shares in the IPO are common to all enterprises. Accordingly, I put forward the following hypothesis:

Hypothesis 1: The level of IPO underpricing of family and non-family firms is similar.

The theory of a hierarchy of financing sources formulated in the 1960s shows that companies prefer internal sources of financing and if there is a need to reach for external ones, then debt is preferred. Research carried out among family firms confirms this theory and also indicates that in family firms an important element to be taken into account in the decision-making process for the selection of financing sources is the desire to maintain full control of the company. Those making financial decisions (board presidents or CFOs) are often at the same time the owners of the company, which means that their decisions are subordinated to a different separate business financial logic (Winnicka-Popczyk, 2008). Family firms most often finance their activities through their own internal capital, and if it is insufficient, they choose borrowed capital (mainly bank credits) and as the last resort they decide to raise capital through external financing of equity (Graves and Thomas, 2008). A feature of small family businesses is access to flexible own financing, which may be the result of, e.g., mobilization of family savings in crisis situations. In this type of companies, an increase in financing from internal 
sources can also result from the reduction of costs associated with remunerations the members of a family in a particular situation may be willing to reduce their salaries or defer their receipt (Alderson, 2009). In subsequent phases of company development, internal financing sources are usually too small to finance growth. In such situations, companies mostly use borrowed capital in the form of bank credits or debt issuance (in the Polish conditions, this is a much less frequently chosen option). When investment needs cannot be fully financed by internal equities and borrowed capital and the owners are unable to set aside additional capital to finance the company, the only way to implement the planned projects is the issue of new shares directed to external investors (KaszubaPerz and Perz, 2013). An external investor may be: another company operating in a similar area (professional investor), a specialized entity engaged in investment activities (PE/VC funds) or a wide range of individual and institutional investors. The choice of the investor the offer is directed to is conditioned by financial and nonfinancial factors.

Financial factors relate mainly to the cost of capital, the risks associated with the financing structure and the level of financial leverage. Non-financial factors relate to the issue of feasibility of obtaining the type of investor, taking control over the company and additional benefits associated with entry of new shareholders to the company. When an offer is directed to a trade investor, the company usually has to establish close cooperation with the new shareholder (access to new markets, technology transfer, joint sales network, joint research and development projects, etc.). PE/VC funds usually support the company in the development and implementation of development strategies, they help in the process of raising capital in the future, as well as acquiring new customers, products and services (usually due to extensive contacts in a given industry). It is also important to support the development cooperation with other actors (within the companies' portfolio held by the fund) as well as a rapid introduction of new products and services into the market (Hellmann and Puri, 2000). An issue directed to a wide range of investors requires the fulfillment of certain formal requirements. Firstly, the company must be a joint stock company, which in the case of most family firms requires a change in the current form of business. In the case of a private issue, the company must draw up an information document and cooperate with an Authorized Adviser of the NewConnect market that will assist the entity in the process of entering the market. The sale of shares in a public offering and entry into the Warsaw Stock Exchange market require a listing particular, which must be approved by the Polish Financial Supervision Authority. The procedure for entry is much longer, more complicated and associated with incurring large financial expenditure. It is also possible to carry out a public offering and introduce shares into the NewConnect market rather than into the Warsaw Stock Exchange. Information on the most important features of the different types of issuance of shares is included in Table 1.

Practice shows that companies that introduce their shares into the NewConnect market almost always choose private issue. This is due to a significantly lower cost of this type of issue, simplified procedures and no necessity to prepare a listing particular. In the sample of researched companies in the years 2013-2015 all companies introduced all their shares in the private issue.

\section{The Activity of Companies on the IPO Market in Poland in the Years 2013-2015}

Table 2 contains the data describing the activity of companies in the process of raising capital in Poland in the alternative trading system NewConnect. In total, in the years 2013-2015 eighty-three companies debuted in Poland and they sold shares worth PLN 182.7 million. The average value of issue in that period was PLN 2.7 million. It is worth noting that the NewConnect market, in addition to raising new capital, allows current owners to sell a part of the previously held shares, which allows for the implementation of strategies of shareholders' partial exit from the company. In the researched period, the value of the shares previously held by the owners that were sold during their IPO on the market had a value of PLN 43.3 million. 
Table 1. Comparison of the characteristics of private and public issue on the Warsaw Stock Exchange and NewConnect

\begin{tabular}{|l|l|}
\hline \multicolumn{1}{|c|}{ Issue type } & \multicolumn{1}{c|}{ The most important features } \\
\hline $\begin{array}{l}\text { Private issue } \\
\text { on the NewConnect market }\end{array}$ & $\begin{array}{l}\text { The issue needs to be addressed to fewer than 150 investors, there } \\
\text { is no need to prepare an issue prospectus, a simplified procedure } \\
\text { of entry, reduced information requirements, low costs associated } \\
\text { with the issue, there is no need to meet the requirements on } \\
\text { issues and the capitalization of the company }\end{array}$ \\
\hline $\begin{array}{l}\text { Public issue } \\
\text { on the NewConnect market }\end{array}$ & $\begin{array}{l}\text { The issue can be addressed to an unlimited number of investors, } \\
\text { the need to draw up an issue prospectus, the prospectus must be } \\
\text { approved by the Polish Financial Supervision Authority, the costs } \\
\text { associated with the issuance are higher than in the private } \\
\text { placement and generally lower than in the case of the issue on the } \\
\text { WSE, no need to meet the requirements for issue values and } \\
\text { capitalization of the company }\end{array}$ \\
\hline $\begin{array}{l}\text { Public issue } \\
\text { on the Warsaw Stock } \\
\text { Exchange }\end{array}$ & $\begin{array}{l}\text { The issue can be addressed to an unlimited number of investors, } \\
\text { the need to draw up an issue prospectus, the prospectus must be } \\
\text { approved by the Polish Financial Supervision Authority, the need } \\
\text { to fulfill disclosure obligations, the company's capitalization must } \\
\text { exceed PLN 60 million }\end{array}$ \\
\hline
\end{tabular}

Source: own study based on materials from the Warsaw Stock Exchange and NewConnect.

Table 2. Number of IPOs and value of capital raised on the NewConnect market in Poland in 2013-2015

\begin{tabular}{|l|c|c|c|c|}
\hline & $\mathbf{2 0 1 3}$ & $\mathbf{2 0 1 4}$ & $\mathbf{2 0 1 5}$ & $\mathbf{2 0 1 3 - 2 0 1 5}$ \\
\hline IPOs number & 42.0 & 22.0 & 19.0 & 83.0 \\
\hline $\begin{array}{l}\text { The value of the capital raised } \\
\text { (PLN million) }\end{array}$ & 95.4 & 27.2 & 60.1 & 182.7 \\
\hline $\begin{array}{l}\text { The shares sold by the current } \\
\text { owners in the offer (PLN million) }\end{array}$ & 7.8 & 19.9 & 15.7 & 43.3 \\
\hline $\begin{array}{l}\text { Total value of the conducted issues } \\
\text { (PLN million) }\end{array}$ & 103.3 & 47.0 & 75.8 & 226.1 \\
\hline $\begin{array}{l}\text { The average value of the issue } \\
\text { (PLN million) }\end{array}$ & 2.5 & 2.1 & 4.0 & 2.7 \\
\hline
\end{tabular}

Source: own study based on data from the NewConnect market.

Table 3 presents the data on the issue of shares on the Warsaw Stock Exchange in 2013-2015. In the analyzed period, the total value of the issue of shares was PLN 7.9 billion. Forty-four companies debuted on the market (excluding the companies that did not carry out a new share issue but only transferred the quotation of their shares from the NewConnect market to the Warsaw Stock Exchange). However, the difference in the value of share issues is important. On the Warsaw Stock Exchange, the average value of the issue of shares was PLN 98.4 million, which means that the average issue of shares is more than
34 times greater than on the NewConnect market.

Due to the fact that by far larger companies which have long history and are in a different stage of development debut on the Warsaw Stock Exchange as compared to the NewConnect market, more business owners decide to sell a part of the stake held during the IPO. The value of shares sold by current owners in the period 2013-2015 amounted to PLN 59 billion. Even taking into account the fact that that value was overvalued by one very large privatized company Energa S.A (PLN 2.4 billion), one can see that on the 
Table 3. Number of IPOs and value of capital raised on the Warsaw Stock Exchange in 2013-2015

\begin{tabular}{|l|c|c|c|c|}
\hline & $\mathbf{2 0 1 3}$ & $\mathbf{2 0 1 4}$ & $\mathbf{2 0 1 5}$ & $\mathbf{2 0 1 3 - 2 0 1 5}$ \\
\hline $\begin{array}{l}\text { Number of IPOs } \\
\text { (Excluding companies coming } \\
\text { from NC) }\end{array}$ & 14 & 15 & 15 & 44 \\
\hline $\begin{array}{l}\text { Companies transferring listing } \\
\text { from NC to WSE }\end{array}$ & 16 & 13 & 8 & 37 \\
\hline $\begin{array}{l}\text { The value of the capital raised } \\
\text { (new shares, PLN million) }\end{array}$ & 464.7 & 400.3 & 1143.5 & 2008.4 \\
\hline $\begin{array}{l}\text { The shares sold by the current } \\
\text { owners in the offer (PLN million) }\end{array}$ & 4230.3 & 888.0 & 845.9 & 5964.1 \\
\hline $\begin{array}{l}\text { Total value of the conducted issues } \\
\text { (PLN million) }\end{array}$ & 4695.0 & 1288.3 & 1989.4 & 7972.6 \\
\hline $\begin{array}{l}\text { The average value of the issue } \\
\text { (PLN million) }\end{array}$ & 204.1 & 46.0 & 66.3 & 98.4 \\
\hline
\end{tabular}

Source: own study based on data from the Warsaw Stock Exchange.

occasion of the debut on the Warsaw Stock Exchange owners quite often decide on strategies of partial exit from the company.

\section{The Activity of Family Firms on the IPO Market in Poland in the Years 2013-2015}

In the literature, there are many various definitions of family firms; an extensive discussion of this issue can be found in the works by Surdej and Wach (2010). In this article, the most common criterion of ownership was used. It was assumed that a family firm was one where members of one family owned more than $25 \%$ of the shares in the company. A similar approach can be found in other works regarding the Polish market (Kowalewski, Talavera and Stetsyuk, 2010); for foreign markets, other values are accepted, e.g., $20 \%$ (La Porta, Lopez-deSilanes and Shleifer, 1999) or 33\% (Barth, Gulbrandsen and Schone, 2005). It is worth mentioning that among the surveyed companies, which were considered as family businesses according to the criterion of ownership, the vast majority of family members also sat on the company management board. Among the 15 companies identified as family ones debuting on the Warsaw Stock Exchange, in only two cases family members did not perform that function. In both cases, family members sat on the company supervisory board. Similarly, in the case of the NewConnect market, among 35 companies identified as family businesses according to the criterion of ownership, family members did not sit on the company management board only in two cases (in one of these companies, they were members of the supervisory board). When identifying family firms, the data from the information documents and listing particulars of companies were used. During the whole period, thirty-six family firms debuted on the NewConnect, which accounts for $43 \%$ of all IPOs. The average value of the issue carried out by a family company totaled 1.9 million, and was, therefore, slightly lower than the average value of the issue for all companies (2.7 million). It is worth noting that shareholders in family firms decided to sell part of their shares less often (only 18\% in the sales of existing shares) than other companies. Table 4 presents data on IPOs of family companies on the NewConnect market.

Table 5 presents the data on IPOs of family firms on the Warsaw Stock Exchange. In the period 2013-2015, among forty-four companies that raised capital, thirteen of them met the criteria of a family firm. The average value of the issue for this group of companies amounted to PLN 99.6 million. Family firms acquired a total of more than PLN 836.2 million from the issue of shares in the period 2013-2015. The introduction of shares into the Warsaw Stock Exchange was rarely associated with the sales of a part of the shares held by the owners. Thus, the proportion of family firms in the value of sold shares amounted to $8 \%$ in all the analyzed period. 
Table 4. The value of capital raised and the number of IPOs among family companies on the NewConnect market in Poland in 2013-2015

\begin{tabular}{|l|c|c|c|c|}
\hline & $\mathbf{2 0 1 3}$ & $\mathbf{2 0 1 4}$ & $\mathbf{2 0 1 5}$ & $\mathbf{2 0 1 3 - 2 0 1 5}$ \\
\hline Number of IPOs & 22 & 7 & 7 & 36 \\
\hline Share in total IPOs & $52 \%$ & $32 \%$ & $37 \%$ & $43 \%$ \\
\hline $\begin{array}{l}\text { The value of the capital raised } \\
\text { (new shares, PLN million) }\end{array}$ & 38.1 & 10.8 & 12.0 & 60.8 \\
\hline $\begin{array}{l}\text { Proportion of the total capital } \\
\text { raised on the NC market }\end{array}$ & $40 \%$ & $40 \%$ & $20 \%$ & $33 \%$ \\
\hline $\begin{array}{l}\text { Shares sold by the current owners } \\
\text { within the offer (PLN million) }\end{array}$ & 2.3 & 1.6 & 3.9 & 7.8 \\
\hline $\begin{array}{l}\text { Proportion of the value of new } \\
\text { shares sold on the NC market }\end{array}$ & $29 \%$ & $8 \%$ & $25 \%$ & $18 \%$ \\
\hline $\begin{array}{l}\text { Total value of the conducted issues } \\
\text { (PLN million) }\end{array}$ & 40.3 & 12.4 & 15.9 & 68.6 \\
\hline $\begin{array}{l}\text { Proportion of the total value of the } \\
\text { issue on NC }\end{array}$ & $39 \%$ & $26 \%$ & $21 \%$ & $30 \%$ \\
\hline $\begin{array}{l}\text { The average value of the issue } \\
\text { (PLN million) }\end{array}$ & 1.8 & 1.8 & 2.3 & 1.9 \\
\hline
\end{tabular}

Source: own study based on data from the NewConnect market.

Table 5. The value of raised capital and the number of IPOs of family firms on the Warsaw Stock Exchange in 2013-2015

\begin{tabular}{|c|c|c|c|c|}
\hline & 2013 & 2014 & 2015 & 2013-2015 \\
\hline Number of IPOs & 4 & 4 & 5 & 13 \\
\hline Share in total IPOs & $29 \%$ & $27 \%$ & $33 \%$ & $30 \%$ \\
\hline $\begin{array}{l}\text { The value of the capital raised } \\
\text { (new shares, PLN million) }\end{array}$ & 59.3 & 218.6 & 558.4 & 836.2 \\
\hline $\begin{array}{l}\text { Proportion of the total capital } \\
\text { raised on the WSE market }\end{array}$ & $13 \%$ & $55 \%$ & $49 \%$ & $42 \%$ \\
\hline $\begin{array}{l}\text { Shares sold by the current owners } \\
\text { within the offer (PLN million) }\end{array}$ & 401.4 & 29.2 & 28.1 & 458.6 \\
\hline $\begin{array}{l}\text { Proportion of the value of new } \\
\text { shares sold on the WSE market }\end{array}$ & $9 \%$ & $3 \%$ & $3 \%$ & $8 \%$ \\
\hline $\begin{array}{l}\text { Total value of the conducted issues } \\
\text { (PLN million) }\end{array}$ & 460.7 & 247.7 & 586.4 & 1294.8 \\
\hline $\begin{array}{l}\text { Proportion of the total value of the } \\
\text { issue on NC }\end{array}$ & $10 \%$ & $19 \%$ & $29 \%$ & $16 \%$ \\
\hline $\begin{array}{l}\text { The average value of the issue } \\
\text { (PLN million) }\end{array}$ & 115.2 & 61.9 & 117.3 & 99.6 \\
\hline
\end{tabular}

Source: own study based on data from the Warsaw Stock Exchange. 


\section{Underpricing of Family Firms' Shares in IPOs in Poland in 2013-2015}

The article analyzes the degree of share underpricing for companies debuting on the Warsaw Stock Exchange and the NewConnect market in 2013-2015. Of all the companies, the group of family companies was distinguished to check whether the degree of underpricing of shares in these companies was different as compared to other firms. The degree of underpricing of shares may be determined by counting the returns from the strategy of buying the shares sold in the IPO and selling them as part of the stock exchange debut. In order to calculate this value, the formula was applied that described a simple rate of return calculated as:

$$
I R_{i}=\frac{P_{i, t}-P_{i, 0}}{P_{i, 0}}
$$

where:

$P_{i, t}-$ IPO price at listing closure, $P_{i, 0}-i$ share price in IPO.

The results are presented in Table 6 .

The results obtained confirm the phenomenon of underpricing of shares sold on the NewConnect market. In the years 2013-2015, the average difference between the sale price of shares in the offer and their stock exchange debut in the alternative trading system amounted to $33.1 \%$. At the same time, the above difference for companies debuting on the Warsaw Stock Exchange amounted to only $3.5 \%$. The significant difference between the level of underpricing of shares in companies making their debut on the NewConnect market and the Warsaw Stock Exchange has important implications for the financial decisions of companies. By issuing shares under a private issue, the company must reckon with a lower valuation of shares sold. From the point of view of share purchasers, a lower valuation is justified by an increased risk resulting from a higher level of information asymmetry. Companies issuing shares in a private issue reveal far less information than in the public offering, making an objective assessment of the current economic situation and development prospects of the company more difficult.

\section{Conclusions}

The issue of shares in a number of growing businesses is the only way to finance the necessary investments. Companies which opt for this form of raising capital have to decide who the shares are sold to and what kind of issues to choose. Companies whose shares are listed in the alternative trading system (NewConnect market) have a choice between a public and private issue, and companies choosing the Warsaw Stock Exchange must perform a public issue. In the years 2013-2015, the issue of shares was carried out in 127 companies (including 49 family firms), the total value of the share issues amounted to almost PLN 8.2 billion (including family firms, nearly PLN 1.4 billion). The analysis confirmed the existence of the share underpricing phenomenon in IPOs. But this

Table 6. Average undervalued shares on the NewConnect market and the Warsaw Stock Exchange in 2013-2015

\begin{tabular}{|l|c|c|c|c|}
\hline & $\mathbf{2 0 1 3}$ & $\mathbf{2 0 1 4}$ & $\mathbf{2 0 1 5}$ & $\mathbf{2 0 1 3 - 2 0 1 5}$ \\
\hline $\begin{array}{l}\text { Average underpricing of shares on } \\
\text { the NC (all companies) }\end{array}$ & $28.6 \%$ & $34.8 \%$ & $35.8 \%$ & $33.1 \%$ \\
\hline $\begin{array}{l}\text { Average underpricing of shares on } \\
\text { the Warsaw Stock Exchange (all } \\
\text { companies) }\end{array}$ & $6.6 \%$ & $1.0 \%$ & $2.9 \%$ & $3.5 \%$ \\
\hline $\begin{array}{l}\text { Average underpricing of shares on } \\
\text { the NC (family firms) }\end{array}$ & $23.2 \%$ & $19.3 \%$ & $45.2 \%$ & $29.2 \%$ \\
\hline $\begin{array}{l}\text { Average underpricing of shares on } \\
\text { the Warsaw Stock Exchange (family } \\
\text { firms) }\end{array}$ & $4.4 \%$ & $2.5 \%$ & $1.8 \%$ & $2.9 \%$ \\
\hline
\end{tabular}

Source: own study based on data from the Warsaw Stock Exchange and NewConnect. 
underpricing is far greater in the case of the issue aimed at the NewConnect market. No significant underpricing difference was observed between family companies and other firms, which could suggest that in the Polish conditions the shareholding structure does not significantly affect the rate of return on IPOs.

\section{References}

Alderson, K.J. (2009). Exploring the complexities of family business decision making: How the second generation makes decisions. Capella: Capella University.

Anderson, R., Mansi S. and Reeb, D. (2006) Ownership structure and corporate decision-making. Journal of Economics and Business, 80, 385-417.

Anderson, R. and Reeb, D. (2003). Founding-family ownership and firm performance: Evidence from the S\&P 500. Journal of Finance, 58, 1301-1327.

Barth, E., Gulbrandsen, T. and Schone, P. (2005). Family ownership and productivity: The role of owner-management. Journal of Corporate Finance, 11(1-2), 107-127.

Craig, J.B. and Salvato, C. (2012). The distinctiveness, design and direction of family business research: Insights from management luminares. Family Business Review, 25, 109-116.

Donaldson, G. (1961). Corporate debt capacity Boston: Harvard University Press.

European Commission. (2009). Overview of familybusiness-relevant issues: Research, networks, policy measures and existing studies. Retrieved from: http:// ec.europa.eu/DocsRoom/documents/10388/attachments/1/translations/en/renditions/pdf (July 2016).

Gemzik-Salwach, A. and Perz, P. (2013). Rynek pierwszych ofert sprzedaży akcji na NewConnect-wybrane zagadnienia. Annales UMCS Sectio H, 47.

Graves, C. and Thomas, J. (2008). Determinants of the internationalization pathways of family firms An examination of family influence. Family Business Review, 21(2), 151-167.

Hellman, T. and Puri, M. (2000). The interaction between product market and financing strategy: The role of venture capital. Rev. Financ. Stud., 13(4), 959-984, http://dx.doi.org/10.1093/ rfs/13.4.959.
Hill, P. (2006). Ownership structure and IPO underpricing. Journal of Business Finance \& Accounting, $33,102-26$

Jewartowski, T. and Lizińska, J. (2012). Short- and long-term performance of Polish IPOs. Emerging Markets Finance \& Trade, March-April, 48(2).

Kaszuba-Perz, A. and Perz, P. (2013). Rola alternatywnych systemów obrotu akcjami w procesie pozyskania kapitału w rozwijajacych sie przedsiebiorstwach. Humanities and Social Sciences, 20(3).

Kowalewski, O., Talavera, O. and Stetsyuk, I. (2010). Influence of family involvement in management and ownership on firm performance: Evidence from Poland. Family Business Review, 23, 45-59.

La Porta, R., Lopez-de-Silanes, F. and Shleifer, A. (1999). Corporate ownership around the world. Journal of Finance, 54, 471-517.

Leitterstorf, M. and Rau, S. (2014). Socioemotional wealth and IPO underpricing of family firms. Strategic Management Journal, May, 35, 751-760, http:/ dx.doi.org/10.1002/smj.2236.

Loughran, T., Ritter, J. and Rydqvist, K. (1994) Initial public offerings: International insights. Pacific-Basin Finance Journal, 2.

Lowry, M. and Shu, S. (2002). Litigation risk and IPO underpricing. Journal of Financial Economics, $65,309-335$.

Melin, L., Nordqvist, M. and Sharma, P. (2013). The $S A G E$ handbook of family business. Kindle Edition. SAGE Publications Ltd.

Perz, P. (2005). Rynek pierwszych emisji publicznych (IPO) - wybrane zagadnienia. e-Finanse Financial Internet Queaterly, (2).

Ritter, J.R. and Welch, I. (2002). A review of IPO activity, pricing and allocations. The Journal of Finance, (4).

Sieradzki, R. (2013). Does it pay to invest in IPOs? Evidence from the Warsaw Stock Exchange, National Bank of Poland. Working paper No. 139/2013.

Surdej, A. and Wach, K. (2010). Przedsiębiorstwa rodzinne wobec wyzwań sukcesji. Warszawa: Difin.

Winnicka-Popczyk, A. (2008). Specyficzne problemy zarządzania finansami w przedsiębiorstwach rodzinnych - wnioski ze studiów literaturowych oraz dotychczasowych badań. Przeglad Organizacji, (3).

Yu, X. and Zheng, Y. (2012). IPO underpricing to retain family control under concentrated ownership: Evidence from Hong Kong. Journal of Business Finance \& Accounting, June/July, 39(5-6), 700-729, http://dx.doi.org/10.1111/j.1468-5957.2011.02278.x. 